\title{
Effect of Composition and Crystallinity of Epitaxial Ni-Zn Ferrite Films by Pulsed Laser Deposition on their Magnetic Properties
}

\author{
Satoshi MIZUKAMI, Kan SHIMIZU, Naoki WAKIYA, Kazuo SHINOZAKI and Nobuyasu MIZUTANI \\ Department of Metallurgy and Ceramic Science, Tokyo Institute of Technology, 2-12-1, Ookayama, Meguro-ku, Tokyo 152-8550
}

\section{PLD 法により作製した Ni-Zn フェライト薄膜の磁気特性に及ぼす組成，結晶性の影響 水上 智·清水 完·脇谷尚樹·篠㟝和夫 · 水谷惟恭 \\ 東京工業大学大学院理工学研究科材料工学専攻, 152-8550 東京都目黒区大岡山 2-12-1}

\begin{abstract}
Epitaxial ( $\mathrm{Ni}-\mathrm{Zn}) \mathrm{Fe}_{2} \mathrm{O}_{4}$ thin film was prepared on $\mathrm{Si}(001)$ substrates using $\left(\mathrm{MgO}-\mathrm{Al}_{2} \mathrm{O}_{3}\right) / \mathrm{CeO}_{2} / \mathrm{YSZ}$ triple buffer layer. In this work, to increase remanent magnetization $\left(M_{\mathrm{r}}\right)$ and decrease coercive field $\left(H_{\mathrm{c}}\right)$, for epitaxial $(\mathrm{Ni}-\mathrm{Zn}) \mathrm{Fe}_{2} \mathrm{O}_{4}$ thin film, the effect of substrate temperature, oxygen pressure and composition on the magnetic properties was examined. It was clarified that the remanent magnetization and coercive field were strongly influenced by temperature and oxygen pressure. In order to obtain high $\boldsymbol{M}_{\mathrm{r}}$ and low $\boldsymbol{H}_{\mathrm{c}}$, it was thought that a substrate temperature of $800^{\circ} \mathrm{C}$ and oxygen pressure $1.3 \mathrm{~Pa}$ were optimal conditions. As regarding the composition, $M_{\mathrm{r}}$ could be obtained to a maximum of $3.96 \times 10^{-1} \mathrm{~Wb} / \mathrm{m}^{2}$ by changing the quantity of $\mathrm{Zn}$ and $\mathrm{Fe}\left(M_{\mathrm{s}}=5.31 \times 10^{-1} \mathrm{~Wb} / \mathrm{m}^{2}, H_{\mathrm{c}}=1.35 \times 10^{1} \mathrm{kA} / \mathrm{m}\right)$.
\end{abstract}

[Received December 17, 2001; Accepted March 25, 2002$]$

Key-words : Pulsed laser deposition, Ni-Zn ferrite, Remanent magnetization, Coercive field, Epitaxial

1. Introduction

Recently, researches for field effect transistor (FET)type ferroelectric random access memory (FRAM) has been extensively carried out. We are considering a possibility that FRAM performance would be modified using ferromagnetic layer. ${ }^{1)}$ To achieve the new memory, the control of the electric current by using Hall effect is the most important and thus ferrite having large remanent magnetization is selected as the ferromagnetic layer. Moreover to achieve maximum performance, heteroepitaxial ferroelectric/ferromagnetic/semiconductor structure is required. Ferroelectric/ferromagnetic heterostructures on Si are first proposed by Wakiya et al.1) They prepared heteroepitaxial $\mathrm{NiFe}_{2} \mathrm{O}_{4}$ thin film on $\mathrm{Si}(001)$ substrate via $\left(5.3 \mathrm{~mol} \% \mathrm{Al}_{2} \mathrm{O}_{3}\right.$ doped-MgO) $/ \mathrm{CeO}_{2} / \mathrm{YSZ}$ buffer layers. ${ }^{2)}$ However, the remanent magnetization $\left(M_{\mathrm{r}}\right)$ of $\mathrm{NiFe}_{2} \mathrm{O}_{4}$ was small and $H_{\mathrm{c}}$ value was large. Therefore, to increase $M_{\mathrm{r}}$ and decrease $H_{\mathrm{c}}$, preparation of heteroepitaxial $(\mathrm{Ni}-\mathrm{Zn}) \mathrm{Fe}_{2} \mathrm{O}_{4}$ on $\mathrm{Si}(001)$ substrate was required. To achieve epitaxial (Ni-Zn) $\mathrm{Fe}_{2} \mathrm{O}_{4}$ thin film, some buffer layers for $\mathrm{NiFe}_{2} \mathrm{O}_{4}$ thin film were used.

The magnetization of $\mathrm{Mn}-\mathrm{Zn}$ ferrite, $\mathrm{Ni}-\mathrm{Zn}$ ferrite has been reported.3)-8) However there are a few researches, which are optimizing substrate temperature, oxygen pressure, and composition in order to acquire the good magnetic characteristic (high $M_{\mathrm{r}}$, low $H_{\mathrm{c}}$ ). Furthermore, the relation of crystalline and the magnetic characteristic has not been clarified yet. In this paper, to improve the soft magnetic properties $\left(M_{\mathrm{r}}, H_{\mathrm{c}}\right)$ of the $(\mathrm{Ni}-\mathrm{Zn}) \mathrm{Fe}_{2} \mathrm{O}_{4}$ thin films, we describe the effect of crystallization on the magnetic properties of $(\mathrm{Ni}-\mathrm{Zn}) \mathrm{Fe}_{2} \mathrm{O}_{4}$ thin films at various substrate temperatures and $\mathrm{O}_{2}$ pressures, and the effect of composition on the magnetic properties of $(\mathrm{Ni}-\mathrm{Zn}) \mathrm{Fe}_{2} \mathrm{O}_{4}$ thin films at constant growth conditions.

\section{Experimental}

2.1 Film preparation and characteristic measurement All thin films were deposited on $\mathrm{Si}(001)$ by pulsed laser deposition with a $\mathrm{KrF}$ excimer laser $(\lambda=248 \mathrm{~nm})$. The laser beam was focused on the target by at an angle of $45^{\circ}$
Table 1. Deposition Conditions of Ni-Zn Ferrite Thin Film

\begin{tabular}{|c|c|}
\hline Laser & $\operatorname{KrF}$ excimer laser $(\lambda=248 \mathrm{~nm})$ \\
\hline Target & $\begin{array}{l}\mathrm{YSZ}(8 \mathrm{Y}), \mathrm{CeO}_{2}, \mathrm{MgO}_{\mathrm{gl}}-\mathrm{Al}_{2} \mathrm{O}_{3}\left(5.3 \mathrm{~mol} \% \mathrm{Al}_{2} \mathrm{O}_{3}\right) \\
\mathrm{Nix}_{\mathrm{x}} \mathrm{Zn}_{\mathrm{y}} \mathrm{Fe}_{3 \times \mathrm{x} \times \mathrm{y}} \mathrm{O}_{4}(0<\mathrm{x}, \mathrm{y}<1.5) \text { ceramic disks }\end{array}$ \\
\hline Target-Substrate distance & $55 \mathrm{~mm}$ \\
\hline Repetition rate & $7 \mathrm{~Hz}$ \\
\hline Spot size & $0.1 \mathrm{~cm}^{2}$ \\
\hline Laser energy density & $2.0 \mathrm{~J} / \mathrm{cm}^{2}$ \\
\hline Film thickness & $\begin{array}{l}\mathrm{YSZ}: 10 \mathrm{~nm}, \mathrm{CeO}_{2}: 18 \mathrm{~nm}, \mathrm{MgO}^{-} \mathrm{Al}_{2} \mathrm{O}_{3}: 3 \mathrm{~nm}, \\
(\mathrm{Ni} \cdot \mathrm{Zn}) \mathrm{Fe}_{2} \mathrm{O}_{4}: 150 \mathrm{~nm}\end{array}$ \\
\hline Substrate temperature & $\mathrm{YSZ}, \mathrm{CeO}_{2}, \mathrm{MgO}^{-} \mathrm{Al}_{2} \mathrm{O}_{3}: 800{ }^{\circ} \mathrm{C}, 650 \sim 800{ }^{\circ} \mathrm{C}$ \\
\hline Oxygen pressure & $\begin{array}{l}\mathrm{YSZ}, \mathrm{CeO}_{2}, \mathrm{MgO}_{\mathrm{Ad}} \mathrm{Al}_{2} \mathrm{O}_{3}: 7.3 \times 10^{-2} \mathrm{~Pa} \\
(\mathrm{Ni} \cdot \mathrm{Zn}) \mathrm{Fe}_{2} \mathrm{O}_{4}: 1.3 \times 10^{-3} \sim 1.3 \times 10^{1} \mathrm{~Pa}\end{array}$ \\
\hline
\end{tabular}

and with a spot size of $0.1 \mathrm{~cm}^{2}$. The laser energy density was about $2 \mathrm{~J} / \mathrm{cm}^{2}$ per pulse, and the laser repetition rate was $7 \mathrm{~Hz}$. The target was kept at a distance of $55 \mathrm{~mm}$ from the substrate and rotated continuously during deposition. The substrates were heated to $800^{\circ} \mathrm{C}$ at a base pressure of $<1.3 \times 10^{-4} \mathrm{~Pa}$. The typical deposition conditions for PLD were shown in Table 1.

The structural properties of the films were characterized by $\mathrm{X}$-ray diffraction (XRD) using $\mathrm{Cu} \mathrm{K} \alpha$ radiation operating at $40 \mathrm{kV}-40 \mathrm{~mA}$ (X'Pert-MPD $(\theta-\theta$, Open Eulerian Cradle), Phillips). The composition of the films was analyzed using an X-ray fluorescent spectroscopy (XRF) (wavelength dispersive spectroscopy (WDS), (PW2404, Phillips, Netherlands)). The magnetization $M_{\mathrm{s}}, M_{\mathrm{r}}$ and the coercive field $H_{\mathrm{c}}$ were measured in the plane of the film using a vibrating sample magnetometry (VSM).

2.2 Deficiency of $\mathrm{Zn}$ in the films as compared with the targets

It is well known that the $\mathrm{MnZn}$-ferrite, NiZn-ferrite films 


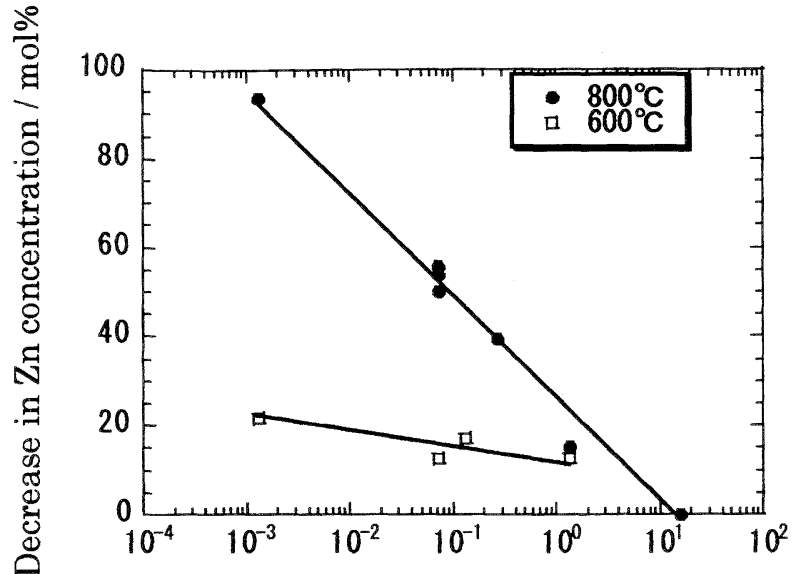

$\mathrm{O}_{2}$ gas pressure / $\mathrm{Pa}$

Fig. 1. Decrease in $\mathrm{Zn}$ concentration(\%) vs $\mathrm{O}_{2}$ gas pressure at $650,800^{\circ} \mathrm{C}$.

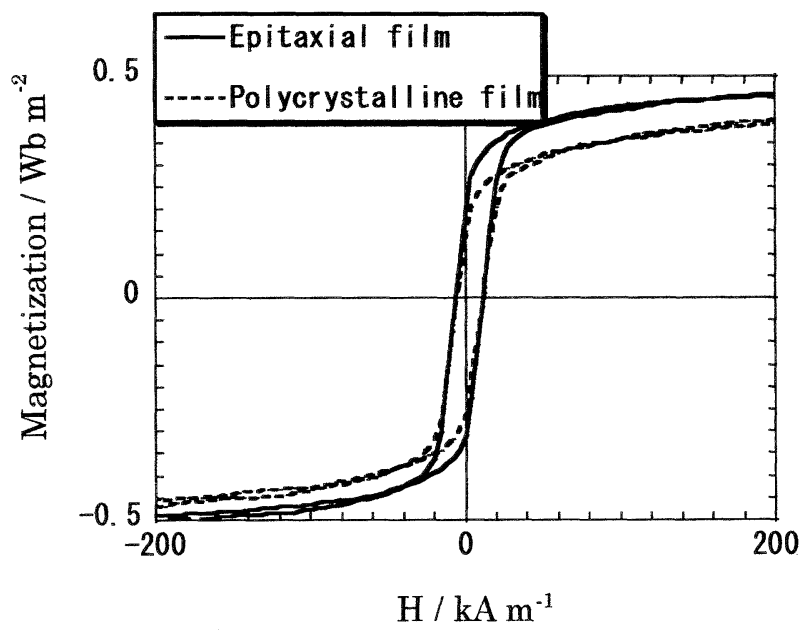

Fig. 2. Effect on the magnetization of epitaxial growth.

were deficient in $\mathrm{Zn}$ as compared to the ferrite targets. ${ }^{3)-7)}$

Figure 1 shows a deficiency of $\mathrm{Zn}$ in the films as a function of substrate temperature and oxygen pressure to prepare for the films with the constant $\mathrm{Ni}, \mathrm{Zn}$ and Fe concentrations irrespective of the deposition conditions. $\mathrm{Zn}$ concentration is decreased with decrease in oxygen pressure at $800^{\circ} \mathrm{C}$, although the data suggest a slight deficiency of $\mathrm{Zn}$ at $650^{\circ} \mathrm{C}$ as compared with the original targets. Therefore in order to compensate for the $\mathrm{Zn}$ deficiency in the films, these targets were prepared with excess $\mathrm{Zn}$ content.

\section{Results and discussion}

3.1 Heteroepitaxial $(\mathrm{Ni}-\mathrm{Zn}) \mathrm{Fe}_{2} \mathrm{O}_{4}$ thin films

In this work, all $\mathrm{Ni}_{x} \mathrm{Zn}_{y} \mathrm{Fe}_{3-x-y} \mathrm{O}_{4}(0 \leqq x, y \leqq 0.9) / 5.3$ $\mathrm{mol} \% \mathrm{Al}_{2} \mathrm{O}_{3}$ doped- $\mathrm{MgO} / \mathrm{CeO}_{2} / \mathrm{YSZ}$ thin films prepared at various substrate temperature $\left(650-800^{\circ} \mathrm{C}\right)$ and $\mathrm{O}_{2}$ pressure $\left(1.3 \times 10^{1}-1.3 \times 10^{-3} \mathrm{~Pa}\right)$ conditions were grown heteroepitaxially on $\mathrm{Si}(001)$.

Figure 2 and Table 2 show the magnetic properties of heteroepitaxial and polycrystalline $\mathrm{Ni}-\mathrm{Zn}$ ferrite films $\left(\mathrm{Ni}_{0.42} \mathrm{Zn}_{0.56} \mathrm{Fe}_{2.02} \mathrm{O}_{4}\right)$ deposited at the same conditions $\left(800^{\circ} \mathrm{C}, 1.3 \mathrm{~Pa}\right)$. The coercive field $H_{\mathrm{c}}$, the saturation mag-
Table 2. Magnetizations for Epitaxial and Polycrystalline Films

\begin{tabular}{lccc}
\hline & $\mathrm{Ms}\left(\mathrm{Wb} / \mathrm{m}^{2}\right)$ & $\mathrm{Mr}\left(\mathrm{Wb} / \mathrm{m}^{2}\right)$ & $\mathrm{Hc}(\mathrm{kA} / \mathrm{m})$ \\
\hline Epitaxial film & $5.10 \times 10^{-1}$ & $2.51 \times 10^{-1}$ & 8.75 \\
Polycrystalline film & $5.04 \times 10^{-1}$ & $1.88 \times 10^{-1}$ & 8.43 \\
\hline
\end{tabular}

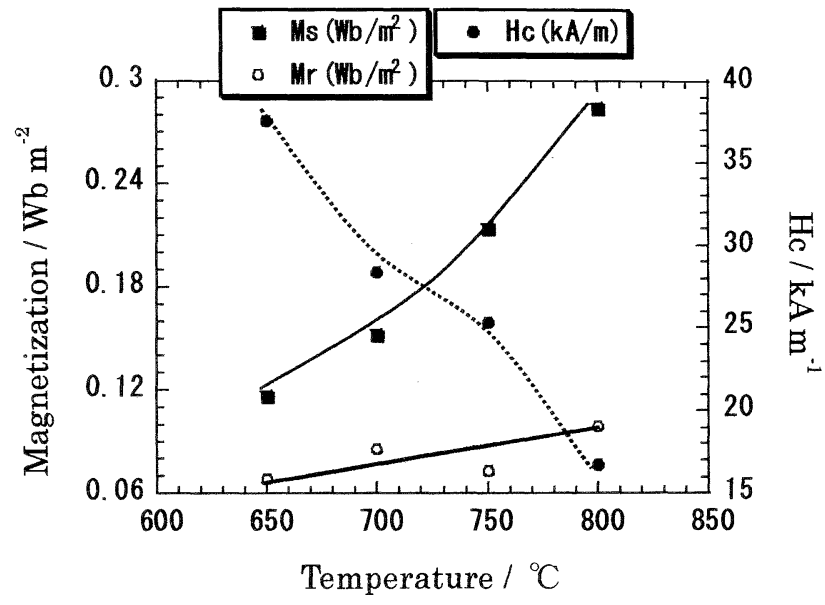

Fig. 3. Comparison of $M_{\mathrm{s}}, M_{\mathrm{r}}$, and $H_{\mathrm{c}}$ for $\mathrm{Ni}_{0.4} \mathrm{Zn}_{0.6} \mathrm{Fe}_{2} \mathrm{O}_{4}$ films as $\mathrm{O}_{2}$ pressure of $7.3 \times 10^{-2} \mathrm{~Pa}$ at $650,700,750$ and $800^{\circ} \mathrm{C}$.

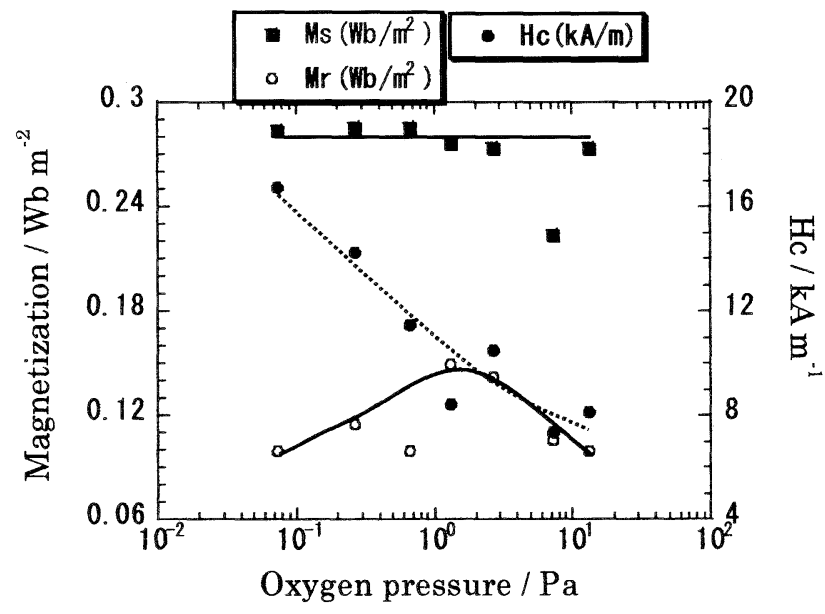

Fig. 4. Comparison of $M_{\mathrm{s}}, M_{\mathrm{r}}$, and $H_{\mathrm{c}}$ for $\mathrm{Ni}_{0.4} \mathrm{Zn}_{0.6} \mathrm{Fe}_{2} \mathrm{O}_{4}$ films as a function of oxygen pressure.

netization $M_{\mathrm{s}}$ of the heteroepitaxial film were very close to the values for polycrystalline film. The remanent magnetization $M_{\mathrm{r}}$, on the other hand, was larger than those of the polycrystalline film. This indicates that $M_{\mathrm{r}}$ is strongly influenced by the heteroepitaxial growth. ${ }^{8)}$

3.2 The magnetic and crystalline properties as functions of substrate temperature and $\mathrm{O}_{2}$ pressure

Figures 3 and 4 show $M_{\mathrm{s}}, M_{\mathrm{r}}$ and $H_{\mathrm{c}}$ as a function of substrate temperature at $\mathrm{O}_{2}$ pressure of $7.3 \times 10^{-2} \mathrm{~Pa}$, and $\mathrm{O}_{2}$ pressure at $800^{\circ} \mathrm{C}$ of substrate temperature, respectively. Generally in composition of $\mathrm{Ni}-\mathrm{Zn}$ ferrite, there are many researches currently studied at a rate of $\mathrm{Ni}: \mathrm{Zn}: \mathrm{Fe}=13.3$ : $20: 66.7 .5), 7)$ Then, it adjusted so that the composition might be set to $\mathrm{Ni}_{0.4} \mathrm{Zn}_{0.6} \mathrm{Fe}_{2} \mathrm{O}_{4}$ in each substrate temperature and oxygen pressure. $H_{\mathrm{c}}$ decreased and $M_{\mathrm{s}}, M_{\mathrm{r}}$, on the other 


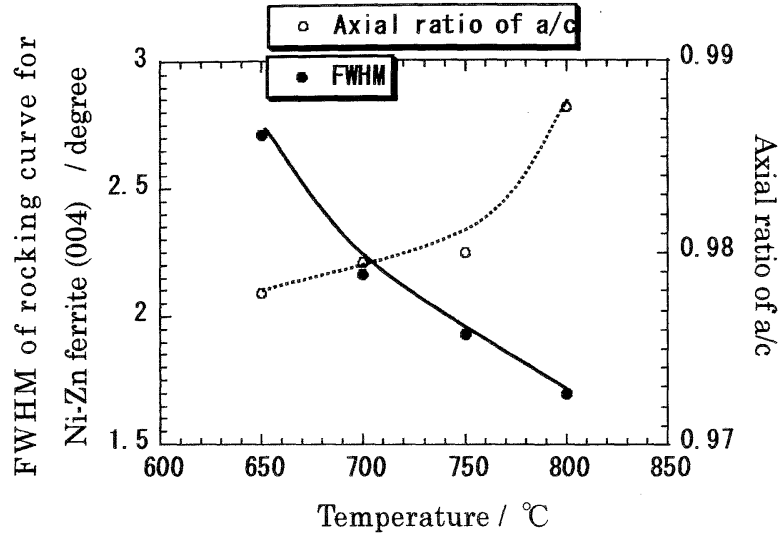

Fig. 5. Change of Ni-Zn ferrite(400) FWHM and axial ratio of $a / c$ with temperature.

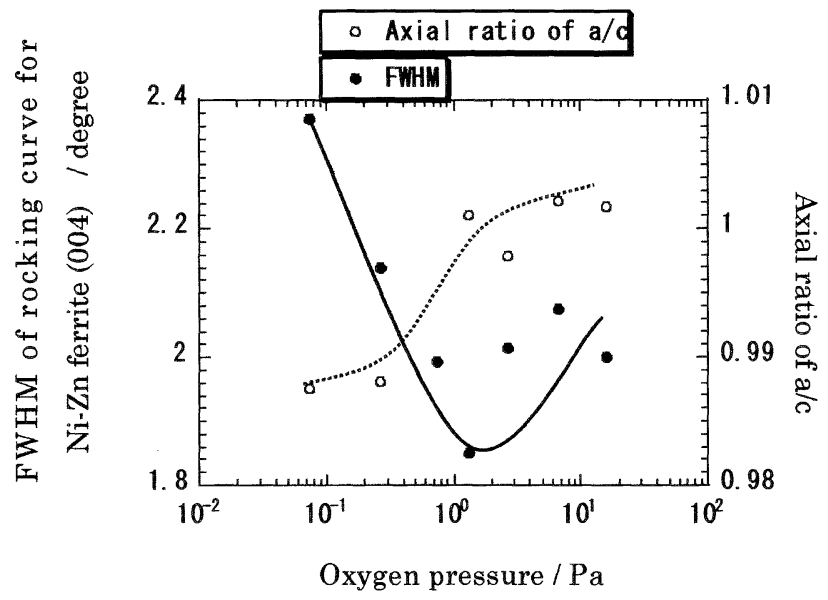

Fig. 6. Relationship between oxygen pressure and FWHM, axial ratio of $a / c$.

hand, increased with increasing substrate temperature (Fig. 3 ). Figure 4 shows $H_{c}$ decreased with increasing $\mathrm{O}_{2}$ pressure, $M_{\mathrm{r}}$ increased with $\mathrm{O}_{2}$ pressure and reached a maximum at about $1.3 \mathrm{~Pa}$, then decreased. However, about 2.76 $\times 10^{-1} \mathrm{~Wb} / \mathrm{m}^{2}$ was shown in every $\mathrm{O}_{2}$ pressure about $M_{\mathrm{s}}$ while $H_{\mathrm{c}}$ and $M_{\mathrm{r}}$ were influenced of $\mathrm{O}_{2}$ pressure.

Figures 5 and 6 show the change of the $\omega$-rocking curve full-width at half maxima (FWHM) for the $\mathrm{Ni}_{0.4} \mathrm{Zn}_{0.6} \mathrm{Fe}_{2} \mathrm{O}_{4}$ (400) peak and axial ratio of $c / a$ as functions of substrate temperature and $\mathrm{O}_{2}$ pressure. The following was considered from these figures, the FWHM value decreased with increasing substrate temperature and ca 1.8 at about $1.3 \mathrm{~Pa}$, $c / a$ increased and approached 1 with increasing substrate temperature and $\mathrm{O}_{2}$ pressure. The relation of $H_{c}$ and temperature is similar to the relation between $c / a$ and substrate temperature, oxygen pressure, and moreover, $M_{\mathrm{r}}$ is similar to the relation of FWHM and these. As substrate temperature is increased, the atomic mobility is enhanced, ${ }^{4)-6)}$ the tilting of the grain boundaries is decreased, and with increasing $\mathrm{O}_{2}$ pressure, the influence by the oxygen defect decreases, the strains are relieved. Consequently, it resulted to reduction in $H_{\mathrm{c}}$. With increasing substrate temperature, and at the reach of $1.3 \mathrm{~Pa}$, the crystalline is improved, and $M_{\mathrm{r}}$ increases.

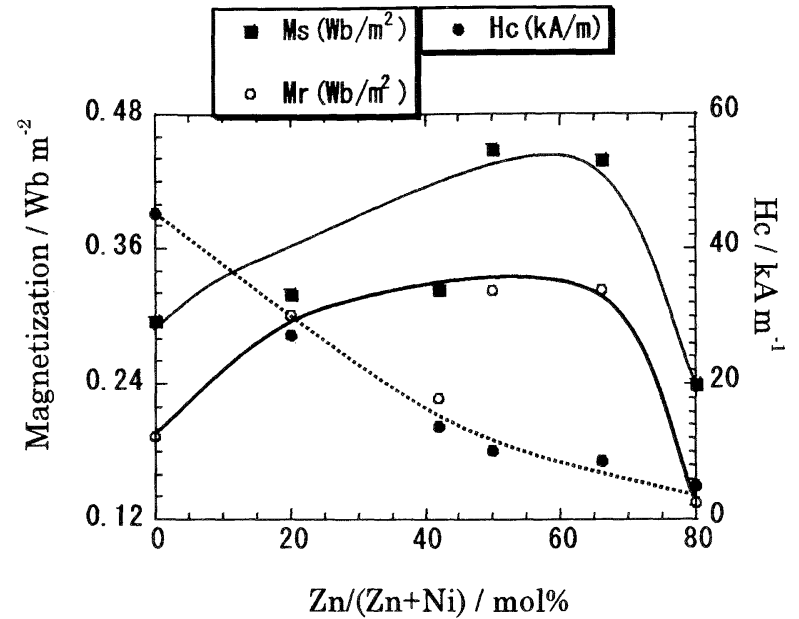

Fig. 7. $M_{\mathrm{r}}, M_{\mathrm{s}}$, and $H_{\mathrm{c}}$ vs $\mathrm{Zn}^{2+}$ ion concentrations of $\mathrm{Ni}_{0.85-x} \mathrm{Zn}_{x}$ $\mathrm{Fe}_{2.15} \mathrm{O}_{4}$.

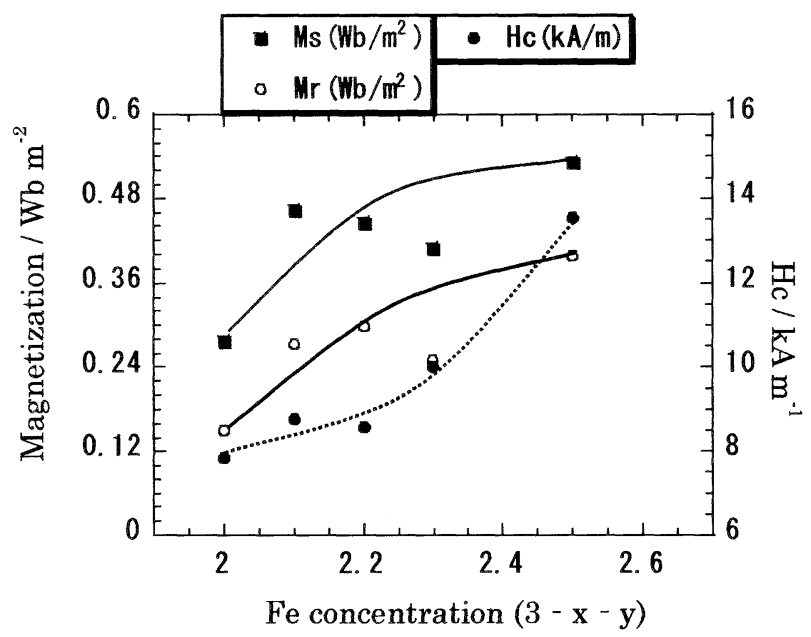

Fig. 8. $M_{\mathrm{s}}, M_{\mathrm{r}}$, and $H_{\mathrm{c}}$ vs Fe concentration of $\mathrm{Ni}_{x} \mathrm{Zn}_{y} \mathrm{Fe}_{3-x-y} \mathrm{O}_{4}(x$ : $y=40: 60$ ).

3.3 The magnetic properties as a function of composition

Figure 7 shows the correlation between the magnetic properties and the $\mathrm{Zn}$ concentration of $\mathrm{Ni}_{0.85-x} \mathrm{Zn}_{x} \mathrm{Fe}_{2.15} \mathrm{O}_{4}$ on at substrate temperature of $800^{\circ} \mathrm{C}, \mathrm{O}_{2}$ pressure of $1.3 \mathrm{~Pa}$. Although $M_{\mathrm{S}}$ and $M_{\mathrm{r}}$ become large with the increase in the amount of $\mathrm{Zn}$ to $(\mathrm{Ni}+\mathrm{Zn})$, they become small if the amount of $\mathrm{Zn}$ to $(\mathrm{Ni}+\mathrm{Zn})$ exceeds $65 \%$. About $H_{\mathrm{c}}$, it becomes small monotonously with the increase in the amount of $\mathrm{Zn}$ to $(\mathrm{Ni}$ $+\mathrm{Zn})$.

The magnetization of the spinel depends on the exchange interaction between oppositely polarized magnetic ions on the tetrahedral-A and octahedral-B sites of the spinel structure. ${ }^{6)}$ It is well known that small increases in the $\mathrm{Zn}$ concentration of a spinel of the type $\mathrm{Me}_{1-x} \mathrm{Zn}_{x} \mathrm{Fe}_{2} \mathrm{O}_{4}$ (Me: metal cation) may enhance the magnetization due to a dilution of the $\mathrm{Fe}^{3+}$ ions on the A sites. However, the magnetic ions of A site may be small, the exchange interaction between A-B may become weak and also even the ferro coupling may disappears by the exchange interaction between other ions if the amount of $\mathrm{Zn}$ becomes superfluous. Consequently, it is thought that magnetization became 


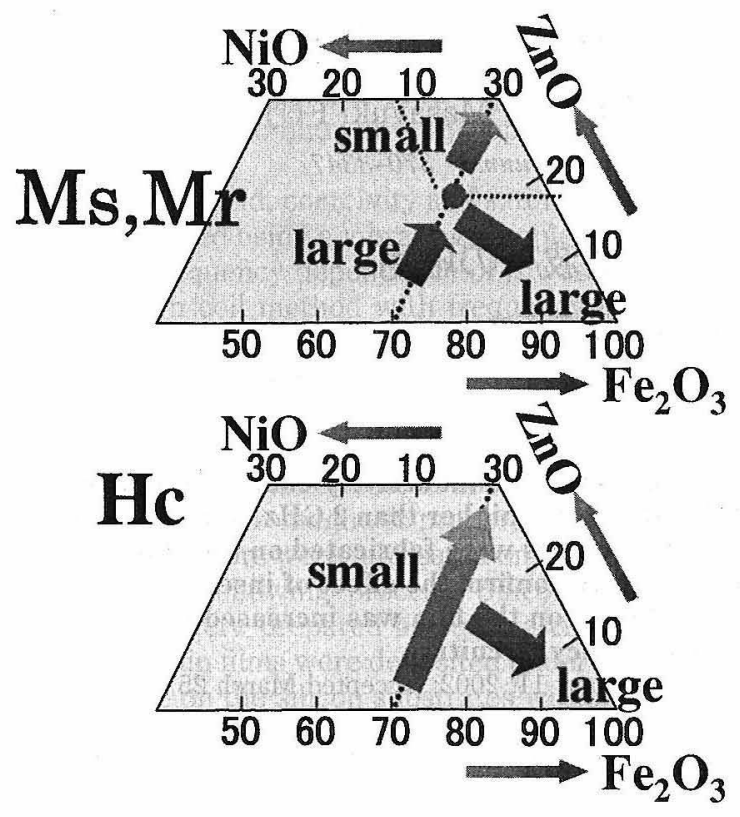

Fig. 9. Magnetic properties of $\mathrm{Ni}_{x} \mathrm{Zn}_{y} \mathrm{Fe}_{3-x-y} \mathrm{O}_{4}$ as a function of composition.

small. Therefore, it turns out that we can get high magnetization by making the amount of $\mathrm{Zn}$ to $(\mathrm{Ni}+\mathrm{Zn})$ into $50-$ $65 \%$.

$M_{\mathrm{s}}, M_{\mathrm{r}}$, and $H_{\mathrm{c}}$ as a function of $\mathrm{Fe}$ concentrations of $\mathrm{Ni}_{x} \mathrm{Zn}_{y} \mathrm{Fe}_{3-x-y} \mathrm{O}_{4}(x: y=40: 60)$ are shown in Fig. 8. In this figure, with the increase in the amount of $\mathrm{Fe}, M_{\mathrm{s}}, M_{\mathrm{r}}$, and $H_{\mathrm{c}}$ become large. The reason can be explained from the following things. There is an excess number of $\mathrm{Fe}^{2+}$ ions on the $\mathrm{B}$ site, and in a magnetic moment, they are $\mathrm{Fe}^{2+}>\mathrm{Ni}^{2+}, \mathrm{Zn}^{2+}$. That is, since the whole amount of magnetic moments becomes large because the quantity of $\mathrm{Fe}$ increases, it is thought that $M_{\mathrm{r}}$ and $M_{\mathrm{s}}$ also became large. Moreover, when $\mathrm{Fe}$ is made superfluous, diffusion of $\mathrm{Fe}^{2+}$ through a positive ion lattice vacancy under crystal becomes easy to take place like $\mathrm{Fe}^{3+}+\mathrm{e}^{-} \rightleftarrows \mathrm{Fe}^{2+}$, and it is thought that the induced magnetic anisotropy increases. That was connected to the increase in $H_{\mathrm{c}}$. As a conclusion of composition, the relation between $\mathrm{Zn}, \mathrm{Fe}$ content, and the magnetic characteristic is shown in Fig. 9.

\section{Conclusions}

Heteroepitaxial (Ni-Zn) $\mathrm{Fe}_{2} \mathrm{O}_{4}$ thin films on $\mathrm{Si}(100)$ substrate via ( $5.3 \mathrm{~mol} \% \mathrm{Al}_{2} \mathrm{O}_{3}$ doped-MgO) $/ \mathrm{CeO}_{2} / \mathrm{YSZ}$ buffer layers have been obtained by PLD on $\mathrm{Si}(100)$ substrate at various substrate temperature and $\mathrm{O}_{2}$ pressure conditions, from targets prepared by various compositions. We have examined the magnetic and crystalline properties to improve the soft magnetic properties $\left(M_{\mathrm{r}}, H_{\mathrm{c}}\right)$ of the $(\mathrm{Ni}-\mathrm{Zn}) \mathrm{Fe}_{2} \mathrm{O}_{4}$ thin films. This investigation shows that $H_{\mathrm{c}}$ and $M_{\mathrm{r}}$ are strongly influenced by the crystalline of the films, and $M_{\mathrm{s}}$, $M_{\mathrm{r}}$, and $H_{\mathrm{c}}$ depend more on the composition. It turns out as conditions for obtaining optimal $M_{\mathrm{r}}$ and $H_{\mathrm{c}}$ that they are the substrate temperature of $800^{\circ} \mathrm{C}$, and $\mathrm{O}_{2}$ pressure of $1.3 \mathrm{~Pa}$. The magnetic properties as a function of composition. It is very likely that the changes in the $M_{\mathrm{s}}, M_{\mathrm{r}}$ and $H_{\mathrm{c}}$ of the films could be due to the presence of $\mathrm{Zn}^{2+}, \mathrm{Fe}^{2+}, \mathrm{Fe}^{3+}$ ions.

Acknowledgements This work was supported by the special coordination fund "Ceramics Integration" from Ministry of Education, Culture, Sports, Science and Technology of Japan.

\section{References}

1) Wakiya, N., Shinozaki, K. and Mizutani, N., Ferroelectrics, 259, 277-82 (2001).

2) Wakiya, N., Shinozaki, K. and Mizutani, N., Key Engineering Mater., 214-215, 171-76 (2002).

3) Dorsey, C. P., Lubitz, P., Harris, G. V., Chrisey, B. D. and Horwitz, S. J., IEEE Tansactions on Magnetics, 31, 3455-57 (1995).

4) Welch, G. R., Neamtu, J., Rogalski, S. M. and Palmer, B. S. Mater. Lett., 29, 199-203 (1996).

5) Welch, G. R., Neamtu, J., Rogalski, S. M. and Palmer, B. S., Solid State Com., 97, 355-59 (1996).

6) Willams, M. C., Chrisey, B. D., Lubitz, P., Grabowski, S. K. and Cotell, M. C., J. Appl. Phys., 75, 1676-80 (1994).

7) Tanaka, K., Omata, Y., Nishikawa, Y., Yoshida, Y. and Nakamura, K., IEEE Tansaction on Magnetics in Japan, 6 , 1001-06 (1991).

8) Kennedy, J. R. and Stampe, A. P., J. Phys. D: Appl. Phys., 32, 16-21 (1999). 